\title{
Impact of Trade Openness on Carbon Productivity of Emerging Economies
}

\author{
Haiyan Ye, Huimin Zhang, Long Wei \\ School of Economics, Wuhan University of Technology, Wuhan, China \\ Email: 276336037@qq.com
}

How to cite this paper: Ye, H. Y., Zhang, H. M., \& Wei, L. (2021). Impact of Trade Openness on Carbon Productivity of Emerging Economies. American Journal of Industrial and Business Management, 11, 19-31. https://doi.org/10.4236/ajibm.2021.111002

Received: December 9, 2020

Accepted: January 11, 2021

Published: January 14, 2021

Copyright $\odot 2021$ by author(s) and Scientific Research Publishing Inc. This work is licensed under the Creative Commons Attribution International License (CC BY 4.0).

http://creativecommons.org/licenses/by/4.0/

\begin{abstract}
Trade openness has a great impact on a country's ecological environment and production technology. A model of trade openness and carbon productivity was constructed based on the panel data as samples obtained from 11 emerging developing countries from 2002 to 2014, effects of technical progress, environmental regulation, and industrial structure upgrading were introduced to study the influencing mechanism of trade openness on carbon productivity, and subgroup test was performed as per the income level. The empirical results show that: 1) On the whole, the relationship between trade openness and carbon productivity is U-shaped. The trade openness, with a purpose of attracting foreign capital, would hinder technical progress and weaken domestic environmental regulation, thus lowering the carbon productivity. Meanwhile, the trade openness also accelerates industrial structure upgrading and therefore improves the carbon productivity. 2) As far as the economies at different income levels are concerned, the trade openness restrains technical progress and lowers the carbon productivity of the countries with uppermiddle-income and high-income, but it accelerates technical progress of the countries with a lower-middle-income; Besides, the trade openness lowers the environmental regulation of the countries with a middle-income and thus decreases the carbon productivity, but it strengthens the environmental regulation of the countries with a high-income and thus increases the carbon productivity; In the meantime, the trade openness can upgrade the industrial structure and improve the carbon productivity of countries at different income levels.
\end{abstract}

\section{Keywords}

Trade Openness, Carbon Productivity, Emerging Economies

\section{Introduction}

An increasing population and the expanding human activities are generating 
more and more greenhouse gas, which leads to global warming, glacial ablation, and ozone depletion, etc. These indisputable facts are damaging the sustainable development of the economy, society and the environment. According to Intergovernmental Panel on Climate Change (IPCC), the global net emissions of $\mathrm{CO}_{2}$ shall be reduced by $45 \%$ by 2030 and reach to near-zero by 2050 , aiming at an amplitude control of the global warming at $1.5^{\circ} \mathrm{C}$. That means the global warming, if emissions of $\mathrm{CO}_{2}$ after 30 years fail to reach zero, would be irreversible, leaving the climate on the earth corrupted. Therefore, countries throughout the world should respond to the climate change as an instant priority. For the emerging economies, they are also taking the heavy responsibility of energy conservation and emission reduction.

Eleven emerging developing countries, with an enormous size of economy and population gross, show a high openness and economic growth rate. They have contributed to the global output greatly in recent years. However, with the increasing growth in foreign trade and economy, these developing countries have also become the fastest growing group of global energy consumption and carbon dioxide emissions. According to the world energy database, China's carbon emission reached 9.43 billion tons in 2018, ranking first in the world, followed by India as the third and Russian the fourth. The carbon emissions of 11 emerging market economies, including South Korea, the Russian Federation, Saudi Arabia, Argentina, Brazil, China, Mexico, South Africa, Turkey, India and Indonesia, have reached 17.17 billion tons, accounting for half of the global carbon emissions. In view of this, it is significant for these 11 countries to increase carbon productivity and realize harmonious development of the economy and the environment by exploring the relationship between trade openness and carbon productivity, thus providing a policy enlightenment to other emerging economies.

\section{Literature Review}

Literature on trade openness and carbon emission mainly focus on the following: one view holds that the trade is beneficial, deeming the trade openness would finally accelerate the economic growth and realize energy conservation and emission reduction. Liu \& Wang (2012) studied the emerging economies and found that the interdependence of export trade would accelerate reduction of carbon emission for developed countries. Liu \& Dong (2017) demonstrated that export trade alleviated the air pollution in China. The other view opposes that trade is harmful, holding the "hypothesis of polluted paradise" and the "hypothesis of sprinting to baseline". These two presumptions hold that the developing countries would weaken their environmental regulation in order to realize the economic growth and expand their competence in trade, which attract the heavy-pollution enterprises from the developed countries and promote the economy at the cost of environment. Sharma (2011) argued the trade openness of developed countries has a positive effect on carbon emission; Li \& Qi (2011) discovered a negative influence of trade openness on the environment in 
China, and the effect of "sprinting to baseline" is more than that of the environmental revenue. AL-Mulali et al. (2015) showed that the export trade has no impact on carbon emission of low-income countries while a positive effect on middle and low-income countries. Hasan et al. (2016) found that trade is a long-term influencing factor of carbon emission, and hypotheses of "polluted paradise" and "sprinting to baseline" are therefore tenable. Yu \& Peng (2017) regarded that liberalization of trade would bring a synchronous increase in the economic aggregate and the carbon emission. For another neutral view, Grossman \& Krueger (1991) divided the environment effects of trade openness into three parts: structural effect, scale effect, and technical effect. The sum of the three determines the impact of trade on the total environment effect with an uncertainty. For example, Kanjilal \& Ghosh (2013) tested the time sequence model of India and found a negative impact of trade openness on carbon emission. Zhan (2017) studied the provincial panel data of China and discovered a threshold effect of trade openness on the environmental regulation; foreign trade and foreign direct investment both impact the carbon emission in China with a significantly regional disparity (Jiang, 2018).

Two methods provided by the current researches are available for the measurement of carbon productivity. One is single factor measurement. Kaya \& Yokobori (1997) defined the carbon productivity as the ratio of output to $\mathrm{CO} 2$ emission, that is, the value created by $\mathrm{CO}_{2}$ emission per unit. The other is total factor measurement based on data envelopment analysis(DEA), which takes labor and capital, etc. into account and regards $\mathrm{CO}_{2}$ as an input variable or "bad" output for measurement (Zhao \& Gao, 2013; Yang et al., 2015). Previous studies have found that factors including technical progress, independent innovation, industry structure, environment regulation, energy efficiency, and foreign direct investment, etc. have different effects on carbon productivity (Zhang et al., 2014; Liu et al., 2015).

Most of the literatures mainly focus on the relationship between trade openness and carbon emission, neglecting the changes on carbon productivity by trade openness and the influencing mechanism of the trade openness. In fact, to increase the carbon productivity can truly realize economic growth and energy conservation as well as emission reduction. Based on the above researches, innovations are put forward for the study: against the backdrop of neglect of the industrial productivity by researches focusing on the effects of trade openness on carbon emission, this study has expounded the influence of trade openness on carbon productivity and used efficiency to measure the degree of environment pollution by trade openness. In addition, intervening variables including technical progress effect, environment regulation effect, and the effect of industrial structure upgrading are introduced to explore the influencing mechanism of trade openness to carbon productivity.

\section{Analysis of Influencing Mechanism}

Trade openness impacts carbon productivity by means of technical progress ef- 
fect, environment regulation effect, and the effect of industrial structure upgrading, with the mechanism shown in Figure 1.

1) Technical progress effect

Technical progress improves the productivity of one country and reduces the energy consumption per unit. But the trade openness would bring either positive or negative technological spillovers. Developing countries usually own a wide market, cheap labor and rich resources. On the one hand, trade openness of the developing countries would attract more foreign investment, then obtain the technological spillovers from developed countries through the model, competition, training effect, and industrial relevant effect by the foreign direct investment, thus promoting their own technical progress (Yang \& Chen, 2015). In addition, outward direct investment would obtain the foreign intelligence and R\&D resource, and benefit from the technological spillovers effect, thus improving the technology level of the domestic enterprises. What is more, trade openness can provide advanced technologies through patent transfer and technology licensing. On the other hand, trade openness would make the developing countries depend on the advanced foreign technologies, failing to realize independent innovation and leaving a negative technology spillover effect. Besides, vicious competition may occur between the local and foreign enterprises, finally resulting in obsolescence of local enterprises due to lag in technology.

2) Environment regulation effect

Since the emerging economies are still in the development phase with immature technologies, they mainly undertake the manufacturing industries that own a low technical content and heavy pollution, which would increase the carbon emission and deteriorate the domestic environment. As a result, these countries respond to the carbon emission through environment regulation to reduce pollution. With the development of the technology and standards of environment regulation, developing countries would actively transfer the procedures with high carbon emission to other countries so as to reduce their own carbon emission. Besides, demands for environment protection in terms of the products by the developed countries would also force the low-carbon technology for an improvement, indirectly increasing the carbon productivity (Xie et al., 2018). But for developing countries in the development phase, they are more likely to focus on growth and attract foreign investment, and give up environment regulation. As a result, the carbon emission is increased and carbon productivity is decreased.

3) Industrial structure upgrading effect

Developing countries are originally distributed in the low-end of the manufacturing industry for a crucial period of transformation, and trade openness would make them ascend the global value chain from the assembly procedure that has low additional value and high energy consumption, and depend on advanced technologies from the developed countries, which are prone to be controlled by the global buyers and transnational corporations, particularly the 


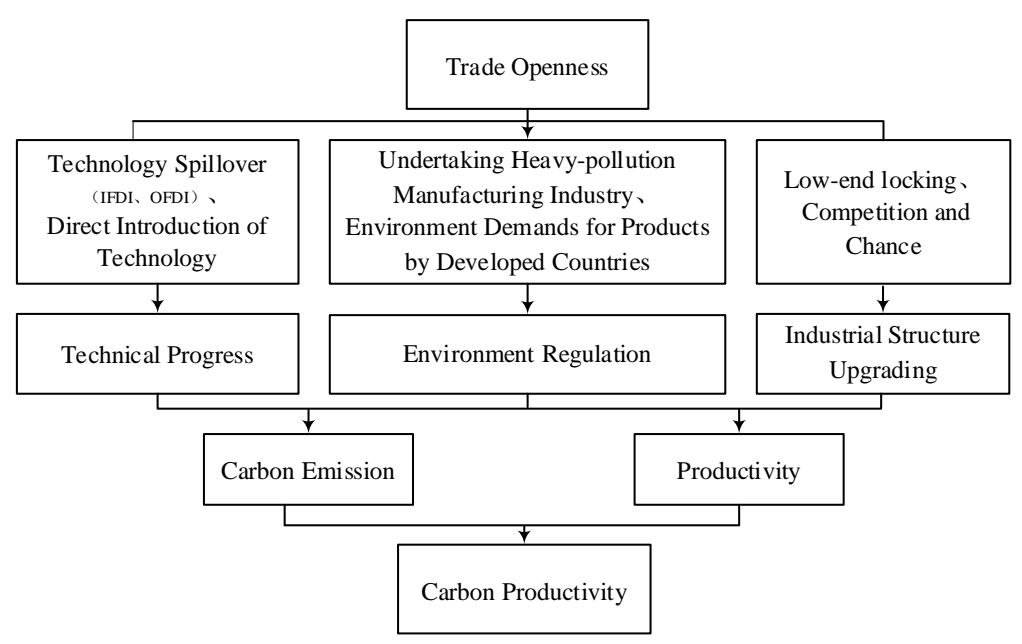

Figure 1. Influencing mechanism of trade openness on carbon productivity.

Chinese manufacturing industry is likely to be hindered and controlled by transnational corporations from developed countries when ascending the middle and high-end of the value chain. As a result, the developing countries are forced to stay at the low-end manufacturing for a low additional value and high carbon emission, and the carbon productivity is also decreased (Humphrey \& Schmitz, 2002). Although mass production in the low-end manufacturing would improve the productivity, it also generates excessive carbon emission and decreases the carbon productivity. The low-end locking effect of trade openness on developing countries would hinder the industrial structure upgrading, but also provide a chance of technology and study. Such effect would stimulate the developing countries with the crisis awareness and force the improvement of industrial structure upgrading. In this way, the productivity is improved, carbon emission is decreased, and carbon productivity is finally raised.

\section{Model Setting and Data Specification}

\subsection{Measurement Model Design}

Considering the non-linear relationship between trade openness of developing countries and carbon productivity, the model for the effects of trade openness on carbon productivity is given as follows:

$$
C P_{i t}=c+\alpha_{0}+\alpha_{1} T O_{i t}+\sum_{i=1}^{n} \beta_{j} \text { Contral }_{i t}+\varepsilon_{i t}
$$

In the above formula, $i$ and $t$ denotes country and year, respectively, $C P_{i t}$ denotes carbon productivity of the explaining variable, $T O_{i t}$ denotes the trade openness level of the core explaining variable, Contral $_{i t}$ refers to the control variables, including technical progress, environment regulation, low-end locking, net inflow of foreign direct investment, energy structure, and urbanization level.

Interaction terms including trade openness and technical progress, environment regulation, and low-end locking are further taken into account to test the 
influencing mechanism of trade openness to carbon productivity. The model setting is seen as follows:

$$
\begin{aligned}
C P_{i t}= & c+\alpha_{0} T O_{i t}+\alpha_{1} T O_{i t}^{2}+\alpha_{2} T O_{i t} * T E_{i t}+\alpha_{3} T O_{i t} * E R_{i t} \\
& +\alpha_{4} T O_{i t} * L O_{i t}+\sum_{j=1}^{n} \beta_{j} \text { Contral }_{i t}+\varepsilon_{i t}
\end{aligned}
$$

In the above formula, $T O_{i t}{ }^{*} T E_{i t}, T O_{i t}{ }^{*} E R_{i t}$, and $T O_{i t}{ }^{*} L O_{i t}$ denote the effects of trade openness on carbon productivity by means of technical progress effect, environment regulation effect, and low-end locking effect, respectively. Other control variables remain unchanged.

\subsection{Variable and Data Specification}

In consideration of availability and continuity of the data and the data missing of some countries for the recent years, equilibrium panel data of the 11 emerging countries from 2002 to 2014 were used; carbon productivity and trade openness were used as explaining variable and core explaining variable, respectively. Interaction terms of trade openness and technical progress, environment regulation, and low-end locking were introduced; net inflow of foreign direct investment, energy structure, and urbanization level were integrated into the model as control variables. Hausman Test was performed to verify whether the model is applicable to the fixed effect model or the random effect model. All the variables are specified as follows:

1) Variables

Carbon productivity (CP). The above-mentioned single factor measurement is used in the study to measure carbon productivity by the ratio of GNP to $\mathrm{CO}_{2}$ emission. The lower the carbon emission, the higher the productivity, and the higher the carbon productivity.

Trade openness (TO). Most scholars adopt dependence on foreign trade to measure the trade openness and reveal the degrees of trade openness from the viewpoint of flux, which is determined by the proportion of the total trade in GNP.

Technical progress (TE). It mainly refers to the green technologies promoting energy conservation and emission reduction and improving carbon productivity. The final outcome of Technical progress is the improvement of productivity and reduction of energy consumption. In view of this, GDP generated by energy consumption per unit is used to measure the overall level of Technical progress. The higher the value, the higher the Technical progress degree.

Environment regulation (ER). Due to the diverse environment regulation indexes adopted by countries or regions, environment performance index (EPI) is used to measure the intensity of Environment regulation. EPI system focuses on the continuity of environment and the current environmental performance of every nation. The higher EPI is, the higher the intensity of Environment regulation.

Industry structure (LO). The percentage of industrial added value in GNP is used to denote one country's industry structure The higher industry structure, 
the more values industry can generate, and the higher productivity. A negative relationship between industry structure and carbon productivity means that the economic entity is impacted by the low-end locking effect, and trade openness hinders the industrial structure upgrading.

Net inflow of foreign direct investment (FDI). Dependence on foreign trade only partially demonstrates the changes of the scale of import/export trade, so the percentage of net inflow of FDI in GNP is selected as a supplement to trade openness to reveal the changes of capital scale and capital flow caused by trade (Yang \& Liu, 2017).

Energy structure (EN). EN also impacts carbon emission and carbon productivity. If one country uses more fossil energy at a lower level of technology than other countries, more $\mathrm{CO}_{2}$ would inevitably be generated and carbon productivity is lowered. The percentage of fossil energy in energy consumption is used as the index of EN. The higher EN is, the more unbalanced EN of one country, prone to pollution-type consumption.

Urbanization level (UR). The improvement of Urbanization level can increase the productivity by providing qualified labors, but the accompanying growth of production and consumption would also aggravate the pollution. In this paper, the proportion of urban population in the total population is used to denote this variable.

2) Data source

Most original data in the study are from WDI of the World Bank. Data related to Environment regulation are obtained from annual Environmental Performance Index (EPI) report. Eleven emerging countries are classified as per the income standard (1987-2015) by the World Bank into Group A as high-income countries (South Korea, Russia, and Saudi Arabia), Group B as Upper-middleincome countries (Argentina, Brazil, China, Mexico, South Africa, and Turkey), and Group C as middle and Lower-middle-income countries (India, and Indonesia). Table 1 is descriptive statistics of the variables. To eliminate the dimension among variables and ensure the comparability, standardization disposal is carried out for the data.

\section{Empirical Analysis}

Based on the influence of trade openness on carbon productivity, technical progress effect, environment regulation effect, and industrial structure upgrading effect are introduced gradually; then the countries are classified as per the income lev$\mathrm{el}$, and the impact of trade openness on carbon productivity is thus studied.

\subsection{Effect of Trade Openness on Carbon Productivity}

Table 2 shows the basic regression results. Columns (1) and (2) show that the coefficient of Trade Openness (TO) is significantly negative, and the coefficient of square term of Trade Openness $\left(\mathrm{TO}^{2}\right)$ is significantly positive, there is a $\mathrm{U}$-shaped relationship between trade openness and carbon productivity. That is, 
Table 1. Descriptive statistics of variables.

\begin{tabular}{ccccc}
\hline Variables & Mean & Std & minimum & Maximum \\
\hline CP (\$/T) & 1553.727 & 1094.389 & 221.870 & 5953.856 \\
TO (\%) & 54.760 & 18.457 & 22.106 & 110.000 \\
TE (\$/KG) & 7.356 & 2.718 & 1.874 & 15.230 \\
ER (Score) & 47.896 & 7.897 & 31.230 & 66.660 \\
LO (\%) & 34.577 & 10.798 & 20.472 & 66.757 \\
FDI (\%) & 2.239 & 1.397 & -0.324 & 8.496 \\
EN (\%) & 82.007 & 12.918 & 51.319 & 99.997 \\
UR (\%) & 67.625 & 18.180 & 28.244 & 91.377 \\
\hline
\end{tabular}

Table 2. Basic regression results.

\begin{tabular}{|c|c|c|c|c|c|c|}
\hline \multirow{2}{*}{$\begin{array}{c}\text { Explanatory } \\
\text { variables }\end{array}$} & OLS & $\mathrm{FE}$ & FE & FE & $\mathrm{FE}$ & $\mathrm{FE}$ \\
\hline & (1) & (2) & (3) & (4) & (5) & (6) \\
\hline TO & $\begin{array}{c}-1.764^{* * *} \\
(-9.69)\end{array}$ & $\begin{array}{c}-0.594^{* * *} \\
(-3.2)\end{array}$ & $\begin{array}{c}-0.413^{*} \\
(1.74)\end{array}$ & $\begin{array}{c}-0.718^{* * *} \\
(-3.31)\end{array}$ & $\begin{array}{c}-0.806^{* * *} \\
(-3.69)\end{array}$ & $\begin{array}{l}0.095 \\
(0.44)\end{array}$ \\
\hline TO2 & $\begin{array}{c}1.640^{* * *} \\
(8.53)\end{array}$ & $\begin{array}{c}0.556^{* * \star} \\
(3.39)\end{array}$ & $\begin{array}{c}0.318^{\star *} \\
(2.07)\end{array}$ & $\begin{array}{c}0.996^{* * *} \\
(4.84)\end{array}$ & $\begin{array}{c}0.444^{\star *} \\
(2.32)\end{array}$ & $\begin{array}{l}0.292 \\
(1.43)\end{array}$ \\
\hline $\mathrm{TE}$ & & $\begin{array}{c}0.531^{* * *} \\
(9.09)\end{array}$ & $\begin{array}{c}1.136^{* * *} \\
(8.00)\end{array}$ & $\begin{array}{c}0.602^{* * *} \\
(5.99)\end{array}$ & $\begin{array}{c}0.651^{* * *} \\
(6.56)\end{array}$ & $\begin{array}{c}1.000^{\star * *} \\
(5.00)\end{array}$ \\
\hline ER & & $\begin{array}{l}0.118^{\star} \\
(1.67)\end{array}$ & $\begin{array}{l}0.111^{*} \\
(1.65)\end{array}$ & $\begin{array}{c}0.509^{* * *} \\
(3.36)\end{array}$ & $\begin{array}{l}0.129 \\
(1.62)\end{array}$ & $\begin{array}{l}0.134 \\
(1.01)\end{array}$ \\
\hline LO & & $\begin{array}{c}-0.183^{* \star} \\
(-2.44)\end{array}$ & $\begin{array}{c}-0.134^{\star \star} \\
(-2.46)\end{array}$ & $\begin{array}{l}-0.173 \\
(-1.00)\end{array}$ & $\begin{array}{c}-0.645^{\star *} \\
(-2.35)\end{array}$ & $\begin{array}{l}0.072 \\
(0.31)\end{array}$ \\
\hline $\mathrm{TO}^{*} \mathrm{TE}$ & & & $\begin{array}{c}-1.86^{\star * *} \\
(-4.93)\end{array}$ & & & $\begin{array}{c}-2.209^{* * *} \\
(-5.72)\end{array}$ \\
\hline TO*ER & & & & $\begin{array}{c}-0.850^{\star * *} \\
(-3.05)\end{array}$ & & $\begin{array}{l}-0.090 \\
(-0.31)\end{array}$ \\
\hline $\mathrm{TO}^{\star} \mathrm{LO}$ & & & & & $\begin{array}{c}0.712^{\star *} \\
(2.27)\end{array}$ & $\begin{array}{l}0.241 \\
(0.93)\end{array}$ \\
\hline FDI & & $\begin{array}{c}0.118^{* *} \\
(2.48)\end{array}$ & $\begin{array}{c}0.101^{* *} \\
(2.21)\end{array}$ & $\begin{array}{c}0.0837^{*} \\
(1.69)\end{array}$ & $\begin{array}{l}0.082 \\
(1.58)\end{array}$ & $\begin{array}{l}0.031 \\
(0.73)\end{array}$ \\
\hline $\mathrm{EN}$ & & $\begin{array}{l}-0.616 \\
(-0.77)\end{array}$ & $\begin{array}{l}-0.322 \\
(-0.53)\end{array}$ & $\begin{array}{l}-0.314 \\
(-0.12)\end{array}$ & $\begin{array}{l}-0.143 \\
(-0.55)\end{array}$ & $\begin{array}{c}-0.319 \\
(-1.6)\end{array}$ \\
\hline UR & & $\begin{array}{l}0.134^{*} \\
(1.65)\end{array}$ & $\begin{array}{l}0.088 \\
(1.35)\end{array}$ & $\begin{array}{l}0.617 \\
(0.22)\end{array}$ & $\begin{array}{l}0.118 \\
(0.41)\end{array}$ & $\begin{array}{c}0.583^{\star *} \\
(-2.4)\end{array}$ \\
\hline Constant & $\begin{array}{c}0.590^{* * *} \\
(15.35)\end{array}$ & $\begin{array}{l}0.056 \\
(0.96)\end{array}$ & $\begin{array}{c}-0.261^{\star * *} \\
(-3.30)\end{array}$ & $\begin{array}{l}-0.007 \\
(-0.04)\end{array}$ & $\begin{array}{l}0.212 \\
(1.23)\end{array}$ & $\begin{array}{c}0.366^{\star *} \\
(2.14)\end{array}$ \\
\hline $\mathrm{N}$ & 143 & 143 & 143 & 143 & 143 & 143 \\
\hline
\end{tabular}

Standard errors in parentheses. ${ }^{* *} p<0.01,{ }^{* *} p<0.05,{ }^{\star} p<0.1$.

carbon productivity decreases first and then increases with the increase of degree of trade openness. The control variable shows a positive significance in technology level, indicating that the technology level contributes to energy conservation and emission reduction, production promotion, and improvement of carbon 
productivity. Environment regulation level is significantly positive. A high level of environment regulation and strict requirement for emission by enterprises help control carbon emission although that may lower the productivity of the enterprises. Overall, the degree of carbon reduction is higher than the reduction of productivity. Index of foreign investment is significantly positive, indicating that the foreign trade of one country can improve the carbon productivity through technological spillovers. Index of urbanization level is significantly positive, indicating that the generation ratio of qualified labors is higher than that of pollution. The low-end locking coefficient and energy structure coefficient are negative, indicating that the low-end locking effect and energy structure would lower the carbon productivity. Potential explanation to the U-type relationship are given: at the beginning of trade openness, the technology of emerging economies is not advanced, and mature application of technologies from the developed countries are insufficient. Technology spillover effect is negative, and the low-end locking at the initial stage would hinder industrial structure upgrading, and industrial enterprises living on fossil fuel would lower the carbon productivity. In the late period of trade openness, the emerging economies have grasped the technologies from developed countries to improve their carbon productivity. At the same time, these emerging economies are also devoting to improving their industrial structure.

Column (3) to (6) in Table 2 show the results of interaction term integrated, which include degree of trade openness and technical progress, environment regulation, and low-end locking. Column (3) gives the regression result of effects of trade openness on carbon productivity by means of technical progress effect. The coefficient is significantly negative. Taking the positive single coefficient of technical progress into account, the strengthen of trade openness hinder the technical progress in turn, which might be because the country is depending on the technologies from developed countries greatly, failing to realize innovation, or is controlled by the developed countries to undertake the low-end manufacturing with heavy pollution. Column (4) shows the results of interaction term of trade openness and environment regulation. The coefficient is significantly negative, and the single coefficient of environment regulation is positive, indicating that trade openness lowers the carbon productivity by lowering the limit of environment regulation. Column (5) shows the results of interaction term of trade openness and low-end locking effect. The coefficient is significantly positive, and the single coefficient of low-end locking effect is negative. With the above-mentioned low-end locking effect to measure the industrial structure, it indicates that trade openness accelerates industrial structure upgrading and improves carbon productivity.

\subsection{Effects of Trade Openness on Carbon Productivity at Different Income Levels}

Table 3 shows the testing results for different income levels. The coefficients of $\mathrm{TO}$ and $\mathrm{TO}^{2}$ are significantly positive, which shows that trade openness and 
Table 3. Regression results of different income levels.

\begin{tabular}{|c|c|c|c|}
\hline \multirow{2}{*}{ Explanatory variables } & $\begin{array}{l}\text { high-income } \\
\text { countries }\end{array}$ & $\begin{array}{l}\text { Upper-middle-income } \\
\text { countries }\end{array}$ & $\begin{array}{c}\text { Lower-middle-income } \\
\text { countries }\end{array}$ \\
\hline & $\mathrm{FE}$ & $\mathrm{FE}$ & $\mathrm{RE}$ \\
\hline TO & $\begin{array}{l}0.152^{* *} \\
(2.38)\end{array}$ & $\begin{array}{l}-0.540 \\
(-0.55)\end{array}$ & $\begin{array}{l}0.157^{\star} \\
(1.94)\end{array}$ \\
\hline TO2 & $\begin{array}{l}0.005 \\
(0.02)\end{array}$ & $\begin{array}{l}0.980 \\
(0.98)\end{array}$ & $\begin{array}{l}-0.946 \\
(-0.79)\end{array}$ \\
\hline $\mathrm{TO}^{*} \mathrm{TE}$ & $\begin{array}{l}-2.134^{*} \\
(-2.00)\end{array}$ & $\begin{array}{l}-1.845^{* *} \\
(-2.04)\end{array}$ & $\begin{array}{l}0.233 \\
(0.15)\end{array}$ \\
\hline $\mathrm{TO}^{\star} \mathrm{ER}$ & $\begin{array}{l}0.561^{\star} \\
(1.83)\end{array}$ & $\begin{array}{l}-0.472 \\
(-0.69)\end{array}$ & $\begin{array}{l}-2.257^{\star} \\
(-1.81)\end{array}$ \\
\hline $\mathrm{TO}^{\star} \mathrm{LO}$ & $\begin{array}{l}0.407^{\star *} \\
(2.16)\end{array}$ & $\begin{array}{c}0.682 \\
(0.7)\end{array}$ & $\begin{array}{l}2.543 \\
(0.97)\end{array}$ \\
\hline $\mathrm{TE}$ & $\begin{array}{l}1.544^{* * *} \\
(2.99)\end{array}$ & $\begin{array}{c}1.402^{* * *} \\
(3.74)\end{array}$ & $\begin{array}{l}0.153 \\
(0.24)\end{array}$ \\
\hline ER & $\begin{array}{l}-0.284^{*} \\
(-1.74)\end{array}$ & $\begin{array}{l}0.152 \\
(0.52)\end{array}$ & $\begin{array}{l}0.827^{*} \\
(1.89)\end{array}$ \\
\hline LO & $\begin{array}{l}-0.465 \\
(-0.16)\end{array}$ & $\begin{array}{l}-0.181 \\
(-0.36)\end{array}$ & $\begin{array}{l}-1.116 \\
(-1.25)\end{array}$ \\
\hline FDI & $\begin{array}{l}0.009 \\
(0.29)\end{array}$ & $\begin{array}{c}0.282^{\star *} \\
(2.52)\end{array}$ & $\begin{array}{c}0.091 \\
(0.156)\end{array}$ \\
\hline EN & $\begin{array}{l}-0.424^{*} \\
(-1.72)\end{array}$ & $\begin{array}{l}-0.454 \\
(0.90)\end{array}$ & $\begin{array}{l}-0.185 \\
(-0.1)\end{array}$ \\
\hline UR & $\begin{array}{c}2.238^{* * *} \\
(3.05)\end{array}$ & $\begin{array}{r}0.346 \\
(0.9)\end{array}$ & $\begin{array}{l}0.379 \\
(1.12)\end{array}$ \\
\hline Constant & $\begin{array}{l}-1.545^{* *} \\
(-2.28)\end{array}$ & $\begin{array}{l}-0.146 \\
(-0.51)\end{array}$ & $\begin{array}{c}0.080 \\
(0.5)\end{array}$ \\
\hline $\mathrm{N}$ & 39 & 78 & 26 \\
\hline
\end{tabular}

Standard errors in parentheses. ${ }^{\star * *} p<0.01,{ }^{* *} p<0.05,{ }^{*} p<0.1$.

carbon productivity have a positive relationship in high-income countries; the relationship between trade openness and carbon productivity in upper-middle-income countries is consistent with that in general, showing a U-shaped relationship. While in the lower-middle-income countries, the $\mathrm{TO}^{2}$ s $\mathrm{s}$ coefficient is negative, and trade openness ultimately reduces carbon productivity. Based on the interaction term analysis, trade openness hinders technical progress of upper-middle-income countries and reduces carbon productivity, but promotes technical progress of lower-middle-income countries which might be because these countries begin with a lower starting point and are easier to absorb advanced technologies than their own. For upper-middle-income countries whose technology has reached a certain level, technical improvement by means of technological spillovers is difficult with limitations. Trade openness lowers the strength of environment regulation in middle-income countries, thus lowering the carbon productivity, but strengthens the environment regulation in highincome countries, thus raising the carbon productivity. This might be because the middle-income countries are underdeveloped with a low cost, and they choose 
to attract more foreign investment to improve domestic economy and market vitality first and pollution control second; on the contrary, high-income countries are usually developed with certain demands for environment quality and energy conservation and emission reduction, and they are competent in pollution detection and control. In summary, trade openness can improve the industry structure and raise carbon productivity. In terms of control variable, technical progress, FDI, and urbanization level are still important factors to improve carbon productivity for every country; and energy structure and industry structure are still significant to reduce the level of carbon productivity. Developing countries should seize chances to attract investment and absorb advanced foreign technologies to achieve industrial structure upgrading, dig new energies and improve the domestic energy structure.

\section{Conclusion and Policy}

Empirical study shows that for the emerging economies, trade openness and carbon productivity have a U-type relationship. Trade openness would restrain technical progress of developing countries which would weaken their environment regulation, increase carbon emission and lower productivity in order to attract foreign investment, thus decreasing the overall carbon productivity. At the same time, trade openness would accelerate industrial structure upgrading of emerging economies and improves the carbon productivity. The income levels show that trade openness restrains technical progress but reduce carbon productivity of upper-middle-income countries, while increases technical progress of lower-middle-income countries. In addition, trade openness weakens the environment regulation and lowers carbon productivity of middle-income countries, while strengthens environment of high-income countries and improves the carbon productivity.

Given the above conclusion, policy proposes are put forward:

First of all, technical progress is crucial to improve carbon productivity, and trade openness can obtain advanced foreign technologies by means of technology spillover effect via absorbing foreign capital and reverse technology spillover effect via investments abroad. At the same time, it might be possible to be controlled by transnational corporations from developed countries in a fixed stage of division of labor, thus hindering the technical progress. Middle-and-high-income countries should protect their advanced technologies and realize innovation in the cooperation of foreign capital, learn from the foreign technologies for independent innovation. Middle and low-income countries should expand trade openness to attract advanced foreign technologies and realize the improvement of carbon productivity.

Second, high-income countries should maintain the current strength of environment regulation, expand green input, and reduce carbon emission, and the government should strictly supervise the enterprises. Middle-income countries should never give up environment regulation or unilaterally seek for high pro- 
duction and high-income. They should selectively introduce the foreign capital, reduce external carbon emission and raise carbon productivity.

Third, emerging economies should seize the chance of trade openness, integrate innovative resources, accelerate the adjustment of enterprises in terms of industrial structure upgrading, low additional value of outward output, and heavy carbon emission; release more labor and production factors, enhance the potential of domestic technologies in the market, and improve the carbon productivity by means of high-tech industry.

Fourth, emerging economies should explore new energies for efficient utilization, such as solar energy and hydrogen energy instead of the fossil energy, to fundamentally reduce carbon emission. For example, the technology of hydrogen energy is still immature, which should be given more emphasis by the government to eliminate carbon emission radically.

The contribution of this paper is to analyze carbon emissions combined with productivity, and explore the mechanism that trade openness affects carbon productivity through the effects of technological progress, environmental regulation and industrial structure. This is of great significance for emerging economies to find ways to reduce carbon emissions and improve productivity, and then achieve coordinated economic and environmental development. However, the deficiency exists in the paper: using national panel data, there is no research on the impact of trade openness on carbon productivity of various industries in emerging economies, which can become the focus of future research.

\section{Acknowledgements}

Sponsored by China National Fund for National Social Science Research Project: On the Core theory of Global Layout for China's Strategic Emerging Industry, 17BJL015.

\section{Conflicts of Interest}

The authors declare no conflicts of interest regarding the publication of this paper.

\section{References}

Al-Mulali, U., Tang, C. F., \& Ozturk, I. (2015). Does Financial Development Reduce Environmental Degradation? Evidence from a Panel Study of 129 Countries. Environmental Science and Pollution Research, 22, 14891-14900. https://doi.org/10.1007/s11356-015-4726-x

Grossman, G. M., \& Krueger, A. B. (1991). Environmental Impacts of a North American Free Trade Agreement. Cambridge MA: National Bureau of Economic Research Working Paper, No. 3914. https://doi.org/10.3386/w3914

Hasan, M. E., Cetin, M., Seker, F., \& Dogan, E. (2016). The Impact of Trade Openness on Global Carbon Dioxide Emissions: Evidence from the Top Ten Emitters among Developing Countries. Ecological Indicators, 67, 543-555.

https://doi.org/10.1016/j.ecolind.2016.03.027 
Humphrey, J., \& Schmitz, H. (2002). How Does Insertion in Global Value Chains Affect Upgrading in Industrial Clusters? Regional Studies, 36, 1017-1027. https://doi.org/10.1080/0034340022000022198

Jiang, H. S. (2018). The Influence of Foreign Trade and FDI on Carbon Emissions. PhD Thesis, Jinan: Shandong University.

Kanjilal, K., \& Ghosh, S. (2013). Environmental Kuznets Curve for India: Evidence form Tests for Cointegration with Unknown Structural Breaks. Energy Policy, 56, 509-515. https://doi.org/10.1016/j.enpol.2013.01.015

Kaya, Y., \& Yokobori, K. (1997). Environment, Energy and Economy: Strategies for Sustainability. Tokyo: United Nations University Press.

Li, K., \& Qi, S. Z. (2011). Trade Openness, Economic Growth and China's Carbon Dioxide Emissions. Economic Research, 11, 60-72.

Liu, C. J., Hu, W., \& Wu, H. H. (2015). Environmental Regulation, Economic Growth and Regional Carbon Productivity: An Empirical Study Based on Provincial Data in China. Research on Financial and Economic Issues, 10, 31-37.

Liu, Q., \& Wang, Y. (2012). An Empirical Study on the Relationship among FDI, Export Trade and Carbon Emissions in Emerging Market Countries. China Soft Science, 4, 97-105.

Liu, X. Y., \& Dong, H. M. (2017). Does Export Trade Aggravate or Alleviate Air Pollution in China-Based on PM2.5 and $\mathrm{SO}_{2}$ Data. Finance and Trade Research, 1, 76-84.

Sharma, S. S. (2011). Determinants of Carbon Dioxide Emissions: Empirical Evidence from 69 Countries. Applied Energy, 1, 376-382. https://doi.org/10.1016/j.apenergy.2010.07.022

Xie, H. Q., Huang, L. Y., \& Liu, D. D. (2018). Does GVC Embeddedness Improve Carbon Productivity of China's Manufacturing Industry? Journal of International Trade, 12, 109-121

Yang, H. L., \& Chen, Z. (2015). The Indirect Mechanism of FDI Level Spillover: A Study Based on Upstream Suppliers. The Journal of World Economy, 3, 123-144.

Yang, K. J., \& Liu, S. Y. (2017). The Correlation Analysis of Trade Openness, Economic Growth and Carbon Emissions: An Empirical Study Based on Emerging Economies. World Economy Studies, 11, 112-120+137.

Yang, X., Li, X. P., \& Zhou, D. C. (2015). Research on the Difference and Convergence of Carbon Productivity in China's Manufacturing Industry. The Journal of Quantitative \& Technical Economics, 12, 3-20.

Yu, L. L., \& Peng, S. J. (2017). Assessment and Prediction of the Impact of Trade Liberalization on China's Carbon Emissions: An Empirical Study Based on GTAP-MRIO Model and GTAP-E Model. Journal of International Trade, 8, 121-130.

Zhan, H. (2017). The Threshold Effect of Trade Openness on China's Carbon Emissions. World Economy Studies, 2, 38-49+135-136.

Zhang, C., Wang, J. K., Shi, W. Y., \& Li, Y. (2014). Factor Decomposition of Regional Carbon Productivity Fluctuation in China. China Population Resources and Environment, 10, 41-47.

Zhao, G. H., \& Gao, W. J. (2013). Measurement and Change Decomposition of Generalized Carbon Productivity Index of China's Industrial Sector Based on Frontier Analysis Method. Chinese Journal of Management Science, 1, 31-36. 